\title{
Perlindungan Hukum terhadap Pangan Lokal dalam Menjalin Kemitraan dengan Toko Modern Kota Palembang
}

\author{
Redi Pirmansyah \\ Universitas Terbuka Palembang \\ Correspondence email: redipirmansyah@ecampus.ut.ac.id
}

\begin{abstract}
Abstrak. Sebagai negara tropis, Indonesia memiliki sumber daya hayati yang melimpah dan berpotensi untuk mengembangkan berbagai jenis pangan yang unik dan khas, sehingga melalui kondisi keanekaragaman pangan tersebut tentunya Indonesia memiliki potensi untuk mencapai ketahanan pangan nasional. Ketahanan pangan adalah kondisi untuk memenuhi kebutuhan pangan rumah tangga tidak hanya dalam jumlah yang cukup, tetapi juga aman, bermutu, bergizi dan beraneka ragam, hal tersebut tertuang dalam Undang-Undang Pangan Nomor 7 tahun 1996.Tujuan penelitian ini adalah untuk mengetahui perlindungan produk pangan lokal dalam melakukan kemitraan dengan toko moderndi Kota Palembang. Jenis penelitian ini adalah deskriptif analisis dengan pendekatan yuridis empiris. Sumber data utama dalam penelitian ini adalah penelitian kepustakaan, yaitu melalui observasi, penelitian, dan pembacaan bahan hukum, pengambilan keputusan dan dokumen yang berkaitan dengan penelitian ini.Hasil penelitian mengemukakan bahwa Peraturan Daerah Kota Palembang Nomor 25 Tahun 20011 Tentang Pendirian Pusat Perbelanjaan Dan Pasar Modern dimana dalam peraturan daerah tersebut mewajibkan kepada setiap pengusaha yang ingin mendirikan pusat perbelanjaan dan pasar modern di wilayah kota palembang wajib memberikan ruang kepada produk-produk lokal termasuk pangan lokal daerah untuk dapat di jual di pusat-pusat perbelanjaan dan pasar modern di kota palembang dengan prinsip saling menguntungkan, jelas, wajar, berkeadilan dan transparan dengan syarat harus memenuhi standar yang telah ditetapkan.
\end{abstract}

Kata Kunci: Produk pangan; Kemitraan; Toko Modern

\begin{abstract}
As a tropical country, Indonesia is rich in biological resources that have the potential to develop a variety of unique and distinctive foods, so that through this food diversity condition, it certainly has the potential for national food security. Food security is a condition for fulfilling household food needs, not only in large enough quantities but must be safe, high quality, nutritious, and diverse, this is stated in the Food Law Number 7 of 1996. The purpose of this study is to determine product protection local food in partnership with modern shops in Palembang City. This type of research is a descriptive analysis with an empirical juridical approach. The main data source of this research is literature study, namely by observing, studying, reading legal materials and decisions and documents related to this research. The results of the study suggest that the Regional Regulation of Palembang City Number 25 of 20011 concerning the Establishment of Shopping Centers and Modern Markets which in this regional regulation obliges every entrepreneur who wants to establish a shopping center and modern market in the city of Palembang must provide space for local products including local food. areas to be sold in shopping centers and modern markets in the city of Palembang with the principle of mutual benefit, clearness, fairness and transparency, provided that they meet the standards set.
\end{abstract}

Keywords: Food products; Partnership; Modern Stores

\section{PENDAHULUAN}

Masyarakat dan pemerintah bersama-sama menyelenggarakan pembangunan negara yang mencakup seluruh aspek kehidupan bangsa, dengan tujuan untuk mewujudkan masyarakat adil, makmur, material, dan spiritual sesuai dengan Pancasila dan Undang-Undang Dasar Negara Republik Indonesia Tahun 1945. Negara Kesatuan Republik Indonesia, dalam lingkungan yang bebas, bersahabat dan damai, dalam suasana kehidupan nasional yang aman, tertib dan bersemangat untuk mewujudkan kemerdekaan, persatuan dan kedaulatan rakyat. Orang-orang yang terlibat merupakan peserta utama dalam pembangunan, dan pemerintah berkewajiban untuk membimbing, melindungi, serta menciptakan suasana dan iklim yang kondusif.

Pembangunan ekonomi suatu negara dapat dicapai melalui hubungan perdagangan internasional dengan negara sekitarnya. Kegiatan ekonomi yang tidak terlepas dari perdagangan internasional adalah kegiatan masuk dan keluarnya modal suatu negara. Hubungan perdagangan internasional sudah berlangsung lama, yakni ada negaranegara yang memiliki kepentingan nasional modern. Perjuangan negara-negara modern untuk pengawasan dan kemerdekaan ekonomi internasional memaksa mereka untuk menjalin hubungan kerjasama dengan negara lain, salah satunya kerjasama ekonomi ASEAN. Kerja sama ekonomi ASEAN dapat menciptakan peluang dan tantangan baru bagi usaha kecil dan menengah (UMKM). 
UMKM adalah kegiatan ekonomi yang dapat menghasilkan barang atau jasa untuk transaksi komersial, khususnya wilayah perkotaan ${ }^{1}$. UMKM memiliki potensi yang sangat besar dalam kemajuan perekonomian Indonesia, hal tersebut sudah dibuktikan bahwa UMKM di Indonesia sudah menyebar luas di seluruh wilayah. Peran UMKM dalam perkembangan perekonomian suatu negara terbukti melalui penciptaan lapangan pekerjaan hingga pelestarian budaya dengan menciptakan industri-industri produk pangan lokal yang kreatif, salah satunya makanan khas daerah. Berdasarkan data Badan Pusat Statistik tahun 2012, jumlah pengusaha di Indonesia adalah 56.339.560 unit, dimana 56.534.592 adalah UMKM, terhitung sekitar 99\%, dan sisanya 0,01\% adalah perusahaan besar ${ }^{2}$.

Pangan merupakan salah satu kebutuhan pokok dari manusia, sehingga industri pangan di suatu daerah selalu tumbuh dan berkembang secara terus menerus dalam memenuhi kebutuhan pokok dari populasi yang ada. Sebagai negara tropis, Indonesia memiliki sumber daya hayati yang melimpah dan berpotensi untuk meluaskan berbagai jenis pangan yang unik dan khas, sehingga melalui kondisi keanekaragaman pangan tersebut tentunya Indonesia memiliki potensi untuk mencapai ketahanan pangan nasional. Ketahanan pangan adalah suatu kondisi untuk memenuhi kebutuhan pangan rumah tangga tidak hanya dalam jumlah cukup, tetapi juga aman, bermutu, bergizi dan beraneka ragam, hal ini diatur dalam Undang-Undang Pangan Nomor 7 Tahun 1996.

Palembang menjadi provinsi terbesar pertama di wilayah Sumatera dengan jumlah penduduk mencapai 1,8 juta jiwa dan kepadatan penduduk $4.800 \mathrm{~km}^{2}$. Sebagai wilayah dengan status provinsi terbesar, Kota Palembang menjadi salah satu wilayah di Pulau Sumatera yang mempunyai berbagai keunggulan sebagai mata pencaharian masyarakat. Berbagai sarana prasarana unggulan, tempat wisata, dan makanan khas menjadi komoditas utama Kota Palembang. Kota Palembang juga menjadi salah satu tempat terkenal di Indonesia dikarenakan menjadi tempat dengan potensi sarana prasarana olahraga kedua terbesar di Indonesia yaitu Jakabaring. Masyarakat Indonesia juga mengenal Kota Palembang dikarenakan makanan khasnya yangdapat ditemui di seluruh wilayah Indonesia yaitu empek-empek. Hal ini dikarenakan potensi bahan baku empek-empek dapat ditemui dengan mudah. Salah satu sektor pangan di Kota palembang adalah mengolah ikan sebagai bahan dasar utama untuk dapat memproduksi beberapa makanan khas daerah, diantaranya yaitu keanekaragaman pempek, kerupuk-kemplang, rujak mie, mie celor, serta kue srikaya yang tidak hanya menjadi oleh-oleh pangan bagi wisatawan melainkan dikonsumsi warga lokal Kota Palembang. Disamping itu produk pangan lokal Kota Palembang sudah dikemas secara modern dan dipasarkan secara global, sehingga UMKM produk pangan lokal di Kota Palembang mengalami peningkatan sebesar 4,80\% di setiap tahunnya

Persoalan terkait produk pangan lokal yang saat ini sedang terjadi tidak dapat dipisahkan dari perkembangan atau perubahan masyarakat sebagai objek kajian sosiologi. Dalam sebuah pandangan praktis pergerakan produk pangan lokal yang dihasilkan oleh industri kecil masih tergolong lamban, hal tersebut dikarenakan bentuk dari pengemasan produk belum dapat dilakukan dengan baik sehingga pasar modern kurang tertarik dalam membantu pemasaran produk pangan lokal tersebut. Upaya peningkatan produk pangan lokal harus memperhatikan aspek kenyamanan dari setiap konsumen agar mampu bersaing dengan produk pangan lokal lainnya. Oleh karena itu, pengkajian produk pangan lokal yang dihasilkan oleh industri kecil harus dipelajari lebih lanjut karena merupakan sebuah landasan penting dalam upaya peningkatan nilai produk olahan home industri di Kota Palembang.

Seiring dengan perkembangan zaman maka upaya dalam pemasaran produk pangan lokal dapat dilakukan dengan menjalin kerjasama antara UMKM dengan toko modern berjenis minimarket seperti Toko Modern. Toko modern adalah toko yang memiliki sistem pelayanan mandiri dengan cara meritel berbagai komoditas. Ketentuan pendirian toko modern tertuang dalam Undang-Undang Nomor 112 Tahun 2007 yang mengatur tentang penataan dan pengembangan pusat perbelanjaan, pasar tradisional, dan toko modern. Upaya membangun toko modern harus menganalisis status sosial ekonomi masyarakat, adanya pasar tradisional dan UMKM di daerah tersebut, sehingga kehadiran toko modern diharapkan mampu bermitra atau bekerjasama dengan UMKM. Kehadiran toko modern dapat memberikan dampak positif bagi UMKM lokal, hal ini dapat menghemat banyak biaya transportasi yang dekat dengan konsumen, seperti kawasan pemukiman dan pemukiman, serta memberikan keuntungan ekonomis, karena banyak produk memberikan fasilitas potongan harga yang dapat membantu konsumen mendapatkan harga yang lebih murah.

\section{METODE}

Penelitian ini bersifat deskriptif- analitik, yaitu memaparkan secara lengkap bagaimana perlindungan produk pangan lokal dalam melakukan kemitraan dengan toko modern di Kota Palembang, dimana untuk selanjutnya dianalisis menggunakan metode empiris, yaitu metode pengecekan data pembantu terlebih dahulu, kemudian dilanjutkan dengan penelitian data asli di lapangan. Sumber data berasal dari literatur dan fakta di lapangan. Penelitian semacam ini biasa juga disebut dengan penelitian pustaka, yaitu proses pengumpulan data dari bahan pustaka atau literatur, hukum dan peraturan yang relevan, serta penelitian tertulis. Metode penelitian ini adalah kualitatif dan

${ }^{1}$ Delmayuni, A. Strategi Peningkatan Daya Saing UMKM Pangan di Kota Palembang. Buletin Ilmiah Litbang Perdagangan 11(1). (2017). 26.

${ }^{2}$ BPS. Indonesia dalam Angka. Indonesia: Badan Pusat Statistik. (2012). 
bertujuan untuk mengembangkan deskripsi naratif dan / atau tekstual dari fenomena dalam penelitian. Sumber data utama dalam penelitian ini adalah penelitian kepustakaan, yaitu melalui observasi, penelitian, dan pembacaan bahan hukum, keputusan dan dokumen yang berkaitan dengan penelitian ini.

\section{HASIL DAN PEMBAHASAN \\ Pengaturan Hukum Terhadap Produk Pangan Menurut Peraturan Perundang-Undangan di Indonesia Undang-undang 18 Tahun 2012 Pangan}

Pada tahun 1996 Pemerintah bersama DPR sudah membuat regulasi mengenai pengaturan masalah pangan pengaturan tersebut diatur dalam Undang-Undang Nomor 7 Tahun 1996 (tentang Pangan), namun seiring dengan perkembangan zaman, undang-undang tersebut tidak lagi memenuhi kebutuhan masyarakat. secara luas dikarenakan adanya dinamika kondisi eksternal maupun internal, demokratisasi, desentralisasi untuk itu perlu adaya perubahan mengenai pengaturan mengenai masalah pangan maka setelah reformasi pada tahun 2012 disahkanlah UndangUndang Nomor 18 Tahun 2012 tentang Pangan. Undang-undang tersebut mengatur masalah pengelolaan pangan, termasuk perencanaan pangan, penyediaan pangan, keterjangkauan pangan, konsumsi dan gizi pangan, keamanan pangan, pelabelan dan periklanan pangan, pengawasan, sistem informasi pangan, penelitian dan pengembangan pangan, kelembagaan pangan, partisipasi sosial dan investigasi.

Selain itu dalam undang-undang ini juga menamanatkan kepada pemerintah daerah untuk terlibat dan bertanggung jawab untuk mengembangkan produk pangan lokal di daerah masing-masing sebagaimana tertuang dalam pasal 12 ayat(2) undang-undang 18 tahun 2012.

\section{Undang-undang 36 tahun 2009}

Pasal 109 dan Pasal 111 (1) Undang-Undang Nomor 36 Tahun 2009 (Tentang Kesehatan) menjelaskan bahwa Pasal 109 mengatur keamanan makanan dan minuman yang mengandung Orang dan / atau badan hukum yang berbahaya yang mengedarkan makanan dan minuman, diproduksi dengan beredar teknologi manipulasi genetik harus memastikan bahwa aman bagi manusia, hewan, dan lingkungan. "Keselamatan" dalam "Kamus Besar Bahasa Indonesia" artinya tidak ada bahaya, tidak kecemasan. Artinya setiap pangan yang diproduksi oleh peserta komersial harus memenuhi standar yang tidak merugikan konsumen, atau tidak ada risiko kesehatan yang menjadi perhatian konsumen. Pasal 111 ayat (1) Undang-Undang Nomor 36 Tahun 2009 tentang kesehatan mengatur bahwa makanan dan minuman yang dikonsumsi masyarakat harus berdasarkan standar dan / atau persyaratan kesehatan. Perlu diingat bahwa tujuan Undang-Undang ini adalah untuk meningkatkan kesadaran kesehatan, kemauan dan kemampuan semua orang untuk mencapai investasi dalam pembangunan sosial ekonomi dan sumber daya manusia yang produktif. (5) Sanksi sebagaimana dimaksud pada ayat (5) melarang peredaran, mencabut makanan dan minuman yang tidak memenuhi persyaratan standar, kesehatan dan / atau bahaya kesehatan, dicabut izin edarnya, serta disita dan dimusnahkan sesuai dengan ketentuan peraturan perundang-undangan konsumen.

\section{Undang-Undang Nomor 8 Tahun 1999}

Dalam undang-undang perlindungan konsumen, undang-undang pangan juga memiliki ketentuan, tetapi undang-undang pangan tidak disebutkan secara eksplisit. Dilarang membeli dan menjual komoditas yang tidak memenuhi persyaratan dan standar yang ditetapkan oleh peraturan perundang-undangan. Pangan yang akan diperdagangkan harus mencantumkan komposisi, aturan pakai, tanggal produksi, dan efek samping dari mengonsumsi pangan tersebut. Oleh karena itu konsumen dapat memilih makanan yang tepat tanpa merugikan konsumen.

\section{Upaya Pemerintah Kota Palembang Untuk Melindungi Produk Pangan Lokal}

Dalam rangka untuk melindungi dan menjaga kelestarian produk pangan lokal agar tidak kalah dengan produk pangan modern pemerintah kota palembang sudah berupaya melakukan terobosan salah satunya dengan mengeluarkan Peraturan Daerah Kota Palembang Nomor 25 Tahun 20011 Tentang Pendirian Pusat Perbelanjaan Dan Pasar Modern dimana dalam peraturan daerah tersebut mewajibkan kepada setiap pengusaha yang ingin mendirikan pusat perbelanjaan dan pasar modern diwilayah kota palembang wajib memberikan ruang kepada produk-produk lokal termasuk pangan lokal daerah untuk dapat di jual di pusat-pusat perbelanjaan dan pasar modern di kota palembang dengan prinsip timbal balik, kejelasan, keadilan, keadilan dan transparansi, asalkan memenuhi standar yang telah ditentukan.

Mengingat banyaknya tindakan ilegal yang dilakukan oleh pihak-pihak yang bersangkutan, maka perlu dilakukan pengetatan izin waralaba. Pengembangan pasar modern baru membutuhkan pengawasan pemerintah dan persetujuan penduduk setempat. Hak waralaba pasar modern ditetapkan oleh pemasok yang menyediakan dana, dan skala pendanaan mereka lebih tinggi dibanding pedagang kecil. Pembentukan waralaba pasar modern semakin cepat dan diharapkan masyarakat sekitar dapat memanfaatkannya sebagai sarana berbelanja. Toko dengan konsep modern yang didirikan oleh pemilik modal besar tentunya akan berdampak besar pada politik penguasaan perdagangan di 
bidang ekonomi. Pemilik usaha kecil harus bersama-sama mengembangkan usahanya sebagai "penyedia barang dan jasa yang mendistribusikan sembako." Jika merasa tidak lengkap, sebaiknya mencari bantuan dari pemerintah daerah untuk mendorong pengembangan usaha pribumi dalam bentuk pinjaman koperasi. Pemberian pedagang kecil yang dibiayai oleh bantuan pemerintah tidak diragukan akan memudahkan masyarakat dalam memenuhi kebutuhannya secara penuh. Bantuan pemerintah daerah kepada pengusaha kecil akan memberi mereka lebih banyak kesempatan untuk berkembang. Selain bantuan materiil, pedagang kecil juga membutuhkan pendampingan berupa perlindungan hukum, yang dapat memastikan pedagang kecil dapat bertahan dengan adanya waralaba pasar modern di sekitarnya. Pedagang kecil bukanlah entitas komersial yang dapat memiliki legitimasi perusahaan seperti halnya waralaba pasar modern, namun permintaan masyarakat terhadap pedagang kecil berupa toko dan warung kecil tetap diharapkan menjadi perpanjangan tangan produsen. Kalaupun sebagian besar tidak memiliki legalitas pendirian usaha, banyak orang masih mengandalkan pencarian sebagai pedagang kecil. (Martinouva, 2017)

Pemerintah juga harus mampu mencegah pelanggaran dengan memberi peringatan dan menghimbau para pemilik usaha waralaba pasar modern untuk menetapkan aturan usaha pasar mikro. Dengan demikian diharapkan pelanggaran pendirian toko kecil dapat dikurangi, agar tidak mengganggu kelangsungan usaha toko kelontong dan pedagang kaki lima terdekat. Dalam Pasal 3 ayat 9, pendirian pasar kecil atau mandiri yang terintegrasi dengan pusat perbelanjaan atau bangunan lain harus memperhatikan kepadatan penduduk, pembangunan permukiman baru, aksesibilitas wilayah dan ketersediaan tempat parkir, dukungan atau ketersediaan infrastruktur, dan lebih banyak warung / toko di pasar tradisional, dengan mini market kecil di dekatnya.

Dari poin-poin di atas kita ketahui bahwa dalam mendirikan pasar kecil kita harus memperhatikan hal-hal tersebut dan tidak menyalahi aturan yang telah ditetapkan agar dapat terjalin persaingan sehat tanpa merugikan pihak manapun. Namun realitanya tidak demikian, karena sebagaimana disebutkan pada poin (e), masih banyak pasar modern yang tidak memperhatikan keberadaan pasar tradisional dan toko kecil di sekitarnya. Hal ini tanpa kita sadari kita bersama, seiring berjalannya waktu kita akan merobohkan warung-warung kecil disekitarnya. Tanpa pertimbangan lebih lanjut, masyarakat otomatis akan beralih ke minimarket baru untuk mendapatkan diskon menarik (discounted price), barang promosi, bonus, hadiah menarik, belum lagi kemudahan lokasi dan jenis produk atau merchandise yang dijual. Jika pemerintah tidak terlibat langsung di bidang ini, maka hal ini akan terjadi di masa mendatang, dan melihat dampak dari perkembangan pasar yang semakin kecil dari waktu ke waktu. Toko kecil yang didirikan puluhan tahun lalu terpaksa tutup karena ketidakmampuan mengembalikan modal, dan semakin sedikit pembeli yang berhenti di depan toko.

Kita tahu langkah pemerintah mengeluarkan kebijakan berupa Walikota Palembang Nomor 25 Tahun 2011 sudah sesuai dengan harapan masyarakat khususnya pengusaha kecil, namun langkah ini belum selesai karena masih banyak ketidakpatuhan dalam bidang ini Konvensi. Selain itu, untuk mengimbangi pertumbuhan seluruh sektor perdagangan eceran, perlu dilakukan penataan di setiap organisasi pasar kecil. Serta perlu adanya pembinaan kepada pedagang tradisional agar dapat mengikuti perkembangan zaman seiring dengan arah perkembangan masyarakat dan perubahan metode berbelanja. Menyikapi pertumbuhan ekonomi Kota Palembang, terbuka peluang usaha pasar kecil dan waralaba untuk membuka lebih banyak usaha. Hal inilah yang perlu dibahas dalam pedoman pembangunan kawasan toko modern yang sudah tidak berlaku lagi dan memperhatikan regulasi yang ditetapkan oleh Pemerintah Kota Palembang.

\section{SIMPULAN}

Berdasarkan uraian diatas maka penulis dapat bahwa pengaturan hukum terhadap produk pangan sesuai dengan peraturan perundang-undangan Indonesia yang tercantum dalam Undang-Undang Nomor 18 Tahun 2012 tentang Pangan dan Pasal 12 (2) Undang-Undang Nomor 18 Tahun 2012 kepada pemerintah daerah untuk terlibat dan bertanggung jawab untuk mengembangkan produk pangan lokal di daerah masing-masing. Undang-Undang Nomor 36 Tahun 2009 disahkan untuk meningkatkan kesadaran kesehatan, kemauan dan kemampuan semua orang, agar semua orang dapat hidup sehat, sehingga mencapai derajat kesehatan masyarakat yang setinggi-tingginya.Ini merupakan investasi dalam pembangunan masyarakat, dan sumber daya manusia dengan produktivitas ekonomi. Akan tetapi, selain pengaturan tentang pangan, ketentuan Pasal 8 (1) (i) dapat dijadikan dasar untuk melindungi konsumen yang membeli pangan yang mengandung zat berbahaya. Dilarang membeli atau menjual komoditas yang tidak memenuhi persyaratan dan standar peraturan perundang-undangan yang ditetapkan. Peraturan Daerah Kota Palembang Nomor 25 Tahun 2011 Tentang Pendirian Pusat Perbelanjaan Dan Pasar Modern dimana dalam peraturan daerah tersebut mewajibkan kepada setiap pengusaha yang ingin mendirikan pusat perbelanjaan dan pasar modern di wilayah kota palembang wajib memberikan ruang kepada produk-produk lokal termasuk pangan lokal daerah untuk dapat di jual di pusat-pusat perbelanjaan dan pasar modern di kota palembang berdasarkan prinsip timbal balik, kejelasan, keadilan, keadilan dan transparansi dengan syarat harus memenuhi standar yang telah ditetapkan. 
Redi Pirmansyah, Perlindungan Hukum terhadap Pangan Lokal dalam Menjalin Kemitraan dengan Toko Modern Kota Palembang

\section{DAFTAR PUSTAKA}

\section{Jurnal}

Delmayuni, A. (2017). Strategi Peningkatan Daya Saing UMKM Pangan di Kota Palembang. Buletin Ilmiah Litbang Perdagangan 11(1):1-26.

Martinouva, R. A. (2017). Perlindungan Hukum Pedagang Kecil dari Keberadaan Franchise Minimarket (Studi Peraturan Walikota Bandar Lampung Nomor 17 Tahun 2009). KEADILAN PROGRESIF, 8(1).

Safitriani, S. (2014). Perdagangan Internasional dan Foreign Direct Investment di Indonesia. Buletin Ilmiah Litbang Perdagangan 8(1): 1-24.

Rahmat, K. (2019). Analisis Dampak Toko Modern Terhadap Keberadaan Usaha Mikro, Kecil, Menengah di Kota Padangsidimpuan. At-Tawassuth Jurnal, 6(1), 208-230

\section{Buku}

BPS. (2012). Indonesia dalam Angka. Indonesia: Badan Pusat Statistik.

Nazir, M. (2005). Metode Penelitian. Jakarta: Ghalia Indonesia.

Sudrajat. (2005). Dasar-Dasar Penelitian Ilmiah. Bandung: Pustaka Setia.

Sunggono, B. (1997). Metodologi Penelitian Hukum. Jakarta: Raja Grafindo Persada.

Sugiyono. (2006). Metode Penelitian Kuantitatif, Kualitatif dan R\&D. Bandung: Alfabeta.

Soekanto, S. (2007). Pengantar Penelitian Hukum. Jakarta: Universitas Indonesia Press.

\section{Peraturan Perundang-Undang}

Undang-Undang Republik Indonesia Nomor 7 Tahun 1996 tentang KetahananPangan (Lembaran Negara Republik Indonesia Tahun 1996 Nomor 12, Tambahan Lembaran Negara Republik Indonesia Nomor 3656);

Undang-Undang Republik Indonesia Nomor 112 Tahun 2007 tentang Penataan dan Pembinaan Pasar Tradisional Pusat Perbelanjaan dan Toko Modern (Lembar Negara Republik Indonesia Tahun 2007 Nomor 53)

Peraturan Daerah Kota Palembang Nomor 25 Tahun 2011 tentang Pedoman Penataan dan Pembinaan Pusat Perbelanjaan dan Toko Modern. 